\title{
Undang-Undang Antikorupsi dalam Bingkai Konstruksi Media
}

\author{
Rr. Ranti Ramandita dan Gati Dwi Yuliana \\ Fakultas Ilmu Komunikasi Universitas Pancasila \\ Email: radenrororantiramandita@gmail.com \\ Email: gati_dwiyuliana@yahoo.com
}

\begin{abstract}
News about Regulations of KPK revision were issued in February 2016 through a pretty high frequency. Every media shows many kind of informations about the discussion of Regulations of KPK revision from many angles. One of online media reported significantly from the side of news intensity than any other media, that media were Republika.co.id. Republika.co.id served 305 news articles in one month appointing two angle of view at once, either the rejecting side or the accepting side of the Regulations of KPK revision. Finally, that dominant exposure becomes an interesting case to know how the construction of news in Republika.co.id about Regulations of KPK issues in February. This research used a Social Media Reality Construction Theory. This research was looking the case through constructivize paradigm and qualitative approach. Republika.co.id news article were the data for this research which were collected with documentation technique. Those data were examined with Zhondang Pan and Gerald Kosicki framing model. The analysis showed that Republika.co.id news construction tend to contra at the Regulations of KPK revision supporter. Agenda setting and ideology take part in choosing the news construction that used by Republika.co.id.
\end{abstract}

Keywords: republika.co.id, construction of social reality, media ideology, framing

\begin{abstract}
Abstrak
Pemberitaan revisi Undang-Undang KPK mencuat pada bulan Februari 2016 melalui frekuensi yang cukup tinggi. Seluruh media menampilkan berbagai informasi terkait pembahasan revisi Undang-Undang KPK dari berbagai sudut pandang. Salah satu media online melakukan pemberitaan dengan signifikan dari segi intensitas pemberitaan dibandingkan media lain, media tersebut adalah Republika.co.id. Republika.co.id telah menyajikan 305 artikel berita dalam satu bulan dengan mengangkat dua sudut pandang sekaligus, baik pihak yang menolak maupun pihak yang mendukung revisi Undang-Undang KPK. Akhirnya, terpaan yang dominan tersebut menjadi hal yang menarik untuk mengetahui bagaimana konstruksi pemberitaan Republika.co.id mengenai isu revisi UndangUndang KPK pada bulan Februari. Penelitian ini menggunakan teori Konstruksi Realitas Sosial Media sebagai pisau analisisnya. Penelitian ini melihat permasalahan melalui paradigma konstruktivis dan dilakukan dengan pendekatan kualitatif. Artikel berita Republika.co.id merupakan data penelitian yang dikumpulkan melalui teknik dokumentasi. Data tersebut dikaji menggunalan analisis framing model Zhongdang Pan dan Gerald Kosicki. Hasil analisis menunjukkan bahwa konstruksi berita Republika.co.id cenderung tidak berpihak terhadap pendukung revisi Undang-Undang KPK. Agenda setting dan ideologi turut berperan dalam menentukan konstruksi pemberitaan yang dilakukan oleh Republika.co.id.
\end{abstract}

Kata Kunci: republika.co.id, konstruksi realitas sosial, ideologi media, framing 


\section{Pendahuluan}

Tindak kejahatan korupsi di Indonesia masih terjadi hingga saat ini. Maraknya kasus korupsi membuat pemerintah Indonesia bersikap lebih tegas dalam menjunjung tinggi hukum, salah satunya ditandai dengan lahirnya Komisi Pemberantasan Korupsi (KPK) (www.jurnalasia. com, 2016). Terhitung pada tahun 2015, KPK telah melakukan 84 kegiatan penyelidikan, 99 penyidikan, dan 91 kegiatan penuntutan, baik kasus baru maupun perkara lanjutan dari tahun sebelumnya. Selain itu, KPK juga melakukan eksekusi terhadap 33 putusan pengadilan yang telah berkekuatan hukum tetap. Lebih dari 198 miliar rupiah telah dimasukkan ke kas negara. (www.kpk.go.id, 2015).

Upaya memberantas tindak korupsi dilakukan KPK dengan berpedoman pada Undang-Undang Republik Indonesia Nomor 30 Tahun 2002 tentang komisi pemberantasan korupsi. Undang-undang tersebut berisikan pasal-pasal yang mengatur kewajiban dan kewenangan lembaga KPK dalam bertugas (www.acarapidana.bphn.go.id ${ }_{2}$ 2011). Undangundang korupsi termasuk dalam Proyeksi Legislasi Nasional (Prolegnas) 2015-2019. Artinya Undang-Undang KPK dimasukan sebagai daftar pembahasan dalam sidang DPR untuk dilakukan revisi (www.antaranews.com, 2016).

Undang-Undang KPK merupakan landasan hukum yang mengatur proses pemberantasan korupsi di Indonesia, sehingga tidak jarang KPK dipandang penting oleh masyarakat. Masyarakat pun tentu berharap KPK dapat menuntaskan tindak korupsi yang merugikan perekonomian Indonesia. Oleh karena itu, media akan selalu memperhatikan dunia seputar lembaga independen tersebut. Isu revisi Undang-Undang KPK menjadi perhatian media karena media harus berjalan sesuai fungsinya sebagai pelapor. Selain itu, media juga perlu memiliki loyalitas pada warga serta selalu memberikan informasi yang dibutuhkan oleh masyarakat, terlebih berkaitan dengan kesejahteraan publik (Kovach, 2006). Undang-
Undang KPK atau Antikorupsi dinilai memiliki hubungan sebab akibat dengan kehidupan masyarakat luas, karena kewenangan tersebut dapat menentukan keberhasilan KPK dalam menguak kasus korupsi yang turut berdampak pada perekenomian negara.

Rencana pembahasan revisi UndangUndang KPK ini melibatkan jajaran petinggi negara, meliputi presiden, DPR RI, serta menteri-menteri terkait. Adapun sebagian pihak tidak menyetujui bila Undang-Undang Nomor 30 tahun 2002 direvisi. Pada keadaan tersebut, media memainkan peranannya bukan hanya sebagai penyebar informasi berskala luas saja, bahkan sebagai pembentuk opini publik. Media menghasilkan sebuah berita yang dapat mempengaruhi persepsi khalayak berdasarkan maksud ataupun kepentingan media itu sendiri.

Pada pertengahan tahun 2015, wacana revisi Undang-Undang KPK menjadi perhatian di Indonesia. Isu mengenai revisi Undang-Undang KPK diangkat oleh pemberitaan media untuk disajikan kepada khalayak luas. Pemberitaan tersebut sebenarnya sudah muncul dari awal tahun 2015, namun sempat teredam yang kemudian mencuat kembali pada bulan Februari 2016 dengan frekuensi yang cukup tinggi.

Pemberitaan revisi Undang-Undang KPK tidak hanya dilakukan oleh media konvensional tetapi juga oleh media online. Media online menyajikan berita revisi UU KPK secara berkesinambungan yang diikuti oleh berita-berita perkembangan dari isu tersebut. Pada bulan Februari 2016, media online yang memberitakan isu tersebut antara lain Sindonews.com, Vivanews.co.id, Kompas.com, Antaranews.com, Okezone.com, Republika. co.id, Detik.com, Tribunnews.com, BBC.com, Tempo.co, Liputan6.com.

Republika.co.id mengangkat isu revisi Undang-Undang KPK dengan menampilkan pihak yang menolak dan pihak yang mendukung upaya revisi. Penolakan terhadap revisi UndangUndang KPK disajikan dengan judul "Sikap PAN: Cabut Revisi UU KPK dari Prolegnas", "Presiden Diminta Hentikan Kelakuan PDIP", 
"HNW: Apa yang Perlu Disosialisasikan dari Revisi UU KPK?", "Datangi Istana, Forum Guru Besar Desak Revisi UU KPK Dibatalkan", "Gerindra Minta Revisi UU KPK Dicabut dari Prolegnas Prioritas", "Ketua MPR: Lebih Baik tak Ada Revisi UU KPK", "Penyadapan oleh KPK tak Perlu Izin", "Ibas: Demokrat Konsisten Tolak Revisi UU KPK”, "KPK Perlu Diperkuat, Bukan Dikebiri" (www.republika.co.id, 30 Maret 2016).

Selain itu, Republika.co.id turut memberitakan pihak yang mendukung revisi Undang-Undang KPK dengan judul "Sikap Plinplan PDIP Soal UU KPK", "Menkumham Minta Masyarakat tak Cepat Emosi Soal Revisi UU KPK", "Pemerintah tak Berencana Cabut Revisi UU KPK", "Fraksi Hanura Dukung Penundaan Revisi UU KPK", "Fraksi Nasdem Ikuti Pemerintah Terkait Revisi UU KPK", "Gerindra Ingin Pengambilan Keputusan Revisi UU KPK Lewat Voting”, “JK: Kenapa KPK tak Mau Diawasi?", "Hanura Konsisten Dorong Revisi UU KPK" (www.republika.co.id, 30 Maret 2016).

Berdasarkan frekuensi pemberitaan dari media online di Indonesia telah membuktikan bahwa isu revisi Undang-Undang KPK memang menjadi sorotan media. Tidak jarang berita muncul dengan judul yang bersifat emosional, sehingga dapat memunculkan pro-kontra di masyarakat. Hal tersebut juga dipicu dari terpaan pemberitaan yang menampilkan dua sudut pandang, antara pihak yang mendukung dan pihak yang menolak revisi Undang-Undang KPK.

Setiap media online mengangkat isu revisi Undang-Undang KPK melalui dua pandangan sekaligus, baik dari pihak yang pro maupun pihak yang kontra terhadap upaya revisi tersebut. Namun, dari keseluruhan media online yang mengangkat isu revisi Undang-Undang KPK, media Republika.co.id merupakan media yang memiliki intensitas pemberitaan lebih tinggi dibandingkan intesitas media online lain. Apabila dihitung secara manual, maka diperoleh Republika.co.id telah menampilkan lebih dari
305 berita pada bulan Februari 2016, sedangkan Okezone.com menampilkan sekitar 80 -an berita, Vivanews.com sebanyak 24 berita, Antaranews. com sebanyak 74 berita, Sindonews.com sebanyak 10.

Jumlah pemberitaan yang dihasilkan oleh Republika.co.id dalam satu bulan cukup signifikan dibandingkan dengan media online lain. Hal tersebut memperlihatkan bahwa Republika.co.id memiliki fokus tersendiri terhadap isu revisi Undang-Undang KPK. Sebagai media online, Republika.co.id hadir tidak hanya untuk menyebarkan informasi, tetapi juga untuk mengedepankan komunitas muslim (Profil Republika.co.id, 2015).

Hal itu diduga dapat memberikan pengaruh ketika Republika.co.id memaknai isu revisi Undang-Undang KPK. Sebagai media online yang bernafaskan agama Islam, tentu Republika.co.id memiliki pandangan pribadi yang berdampak pada pengemasan bingkai berita terhadap isu ini. Hal tersebut berpotensi menciptakan pemaknaan tersendiri dari pembaca Republika.co.id.Secara sederhana saja, perhatian penuh yang dilakukan Republika.co.id dalam bulan Februari 2016 dari segi frekuensi memperlihatkan perbedaannya dengan media online lain.

Media Republika.co.id mengangkat isu revisi Undang-Undang KPK melalui intensitas yang tinggi dengan dua sudut pandang sekaligus. Sorotan khusus dari Republika.co.id tersebut menghasilkan sebuah tanda tanya terkait pemahaman dan pandangan Republika.co.id terhadap isu revisi Undang-Undang KPK. Hal tersebut dapat terlihat saat mengetahui konstruksi pemberitaan revisi Undang-Undang KPK yang dilakukan oleh Republika.co.id dalam satu bulan tersebut. Dalam perspektif ilmu komunikasi, konstruksi pemberitaan dapat dijelaskan dengan analisis framing. Analisis framing dapat memungkinkan seseorang melihat bagaimana suatu realitas dikonstruksi oleh sebuah media. Analisis framing juga dapat menjelaskan isu mana yang ditonjolkan dan yang disembunyikan.

Model analisis framing yang dianggap 
mampu menjelaskan fenomena pemberitaan revisi Undang-Undang KPK oleh Republika. co.id adalah analisis model Zhongdang Pan dan Gerald M. Kosicki. Analisis tersebut menjelaskan bagaimana media memusatkan perhatian, mengemas dan membingkai berita. Analisis framing model Zhongdang dapat menjelaskan mengenai cara media membentuk konstruksi atas realitas, menyajikannya dan menyampaikannya kepada khalayak melalui empat perangkat framingnya, yakni sintaksis, skrip, tematik, dan retoris.

Konstruksi realitas pertama kali dikenal saat dicetuskan oleh Peter L. Berger. Konstruksi tidak hanya berlaku pada sebuah bangunan, tetapi juga pada sebuah realitas yang terjadi di masyarakat. Beberapa realitas yang terjadi dapat dikonstruksikan untuk memenuhi sebuah kepentingan, misalnya realitas politik ataupun realitas sosial.

Konstruksi realitas politik yang menjelaskan terjadinya proses pengemasan terhadap isu-isu politik yang hidup di masyarakat. Proses pengemasan tersebut melibatkan aspekaspek yang saling berkaitan guna mencapai kepentingan politik, yaitu penggunaan bahasa dan simbol, pemilihan fakta, dan adanya agenda untuk merilisnya (Hamad 2004). Ketiga hal tersebut menjadi dasar dalam strategi pengemasan hingga menghasilkan sebuah konstruksi realitas politik. Konstruksi realitas politik cukup bersifat krusial karena menyangkut kepentingankepentingan lain, seperti kepentingan ekonomi, ideologis, dan idealisme. Hal tersebut tentu memiliki sedikit banyak pengaruh pada proses pengemasan realitas politik.

Berdasarkan hal di atas, maka dapat dikatakan bahwa konstruksi sendiri merupakan strategi penyusunan dalam menciptakan segala sesuatu yang dapat dibangun, termasuk sebuah realitas. Salah satu pelaku konstruksi realitas adalah media. Media mengolah realitas-realitas yang terjadi dan dikonstruksikan hingga mewujudkan sebuah berita untuk disajikan kepada khalayak (Sobur, 2012). Dalam konstruksi realitas politik, tidak jarang aktor politik pun memanfaatkan kekuatan media untuk memenuhi kepentingan politik. Selain realitas politik, realitas sosial juga menjadi salah satu realitas yang dapat dikonstruksikan dan melalui beberapa tahapan yang dijelaskan oleh Berger dan Luckmann.

Mulanya, Berger dan Luckmann mejelaskan realitas sosial dengan memisahkan antara 'realitas' (kenyataan) dan 'pengetahuan'. Apa yang dianggap nyata oleh seseorang belum tentu dianggap nyata pula oleh individu lain, dan tiap individu memiliki pengetahuan yang berbeda-beda (Berger, 1991). Berger dan Luckmann membedakan kedua aspek tersebut dengan contoh apa yang dianggap nyata oleh seorang penjual beras akan berbeda dengan apa yang dianggap nyata oleh seorang manajer bank. Selain itu contoh lain, pengetahuan seorang dokter dengan pengetahuan seorang hakim berbeda. Dalam konteks sosial, ketika seseorang mengartikan sebuah realitas maka yang membedakan adalah pengetahuan sosial yang dimilikinya.

Proses sosial memandang manusia sebagai pencipta realitas sosial yang relatif bebas untuk bertindak di dalam dunia sosialnya. Terdapat pengakuan bahwa kehadiran setiap individu menjadi penentu dalam dunia sosialnya yang dikonstruksi berdasarkan kehendaknya. Individu manusia tidak hanya memiliki ketergantuangan dengan lingkungan alam tertentu tetapi juga dengan budaya sosial yang hidup didalamnya (Berger, 1991). Tiap individu memiliki kemampuan untuk mengolah diri dari bebagai stimulus yang masuk ke dalam dirinya, khusunya dalam bentuk informasi. Serta individu mampu untuk membangun dan menghasilkan konstruksi sendiri terhadap realitas di lingkunganya.

Konstruksi realitas dilakukan

oleh seorang komunikator dalam upaya menyampaikan sebuah makna yang disusun berdasarkan realitas yang terjadi. Sadar atau tidak, faktor yang mempengaruhi konstruksi tersebut memungkinkan makna yang diperoleh komunikan berbeda dengan makna dari realitas 
sebenarnya. Sehingga konstruksi realitas yang tersampaikan bukanlah realitas kedua melainkan dapat membentuk realitas lain (Hamad, 2010). Setiap komunikator tidak dapat dipastikan memiliki pandangan yang sama terhadap suatu realitas yang terjadi, sehingga makna yang terbentuk dalam kognitif komunikan belum tentu sesuai dengan makna yang seharusnya pada realitas yang pertama.

Eksistensi individu mempengaruhi realitas sosial yang terjadi. Realitas sosial akan memiliki makna tersendiri ketika realitas tersebut dikonstruksikan secara subyektif oleh sebuah lembaga yang kemudian akan dipandang obyektif oleh individu lain. Objektivitasi dari konstruksi realitas tersebut akan tetap diterima oleh individu apabila individu tidak memahami tujuan atau kepentingan lain yang ada di dalamnya (Berger, 1991). Lembaga disini digambarkan kepada sebuah media.

Oleh karena itu, Berger dan Luckmann (1991) mengatakan bahwa masyarakat maupun institusi sosial pada kenyataannya diciptakan dari pandangan subyektif. Melalui proses interaksi sosial, suatu realitas akan didefinisikan secara obyektif apabila terjadi penegasan secara terus menerus dengan berbagai makna simbolis yang bersifat universal. Berger dan Luckmann menyebut proses tersebut sebagai proses dialektika yang terjadi melalui tiga tahapan atau momen.

Pertama, eksternalisasi dalam proses dialektis merupakan momen dimana seseorang mengakui keberadaannya dalam sebuah lingkungan manusia, baik secara mental maupun fisik. Masyarakat merupakan produk manusia yang memiliki perlaku tak terbatas terkadang memerlukan arah dan stabilitas untuk mengaturnya. Individu merupakan bagian dari produk manusia yang selalu berkembang setiap harinya sebagai sesuatu yang berbeda dalam formasi sosiokultural dan psikologis (Berger,1991). Produk manusia memiliki perilaku yang dinamis dan selalu terjadi dalam masyarakat. Manusia tidak dapat memaksa diri untuk tertutup terhadap lingkungan, sehingga manusia akan menemukan dirinya di dalam dunia ia berada.

Kedua, objektivasi adalah tahapan yang dihasilkan dari eksternalisasi. Hasil dari eksternalisasi tersebut dipandang secara nyata dan berbeda dengan anggapan manusia. Alat, bahasa, pengalaman, dan makna akan menjadi objektif ketika dilihat oleh individu. Bahasa sebagai hasil eksternalisasi yang bersifat objektif memiliki kekuatan untuk membangun sebuah realitas dalam kehidupan sehari-hari. Bahasa akan menciptakan simbol-simbol dimana maknanya dapat berbeda-beda (Berger, 1991).

Secara sederhana, setelah seseorang beradaptasi dengan lingkungan dimana ia berada, ia akan menghadapi sebuah realitas yang dianggap fakta namun dipandang secara objektif. Dalam hal ini pengetahuan akan menentukan pandangan objektif seseorang terhadap suatu realitas. Bagi individu yang memiliki pengetahuan yang sama maka realitas tersebut menjadi bersifat subjektif (proses institusionalisasi).

Kemudian yang ketiga adalah tahapan internalisasi. Momen ini merupakan tahapan ketika seluruh hasil eksternalisasi dan objektivasi diserap kembali oleh individu sehingga pandangan objektif tersebut diakui sebagai kebenaran yang valid dalam dunia sosial. Pandangan terhadap realitas secara tidak disadari akan masuk ke dalam sisi kognitif individu kemudian disubjektifkan. Dengan internalisasi, dunia sosial terlihat menjadi realitas yang subjektif nyata bagi individu (Berger, 1991).

Proses dialektika terjadi dalam kehidupan masyarakat. Melalui tiga tahapan yang dikemukakan oleh Berger dan Luckmann, seseorang akan mengalami proses pengakuan diri (eksternalisasi) sehingga ia akan melihat berbagai realitas di luar (objektivasi). Berdasarkan pengetahuan, pemaknaan, dan pengalaman, seseorang akan menciptakan atau membangun respon, baik dalam bentuk perilaku maupun fikiran. Kemudian hasil tersebut diserap kembali ke dalam diri (internalisasi).

Setiap inidvidu merupakan produk sosial yang mampu menciptakan produk budaya 
yang dapat dipandang subjektif oleh dunia. Hal tersebut dibedakan berdasarkan pengalaman, pengetahuan, serta identitas sosial. Peran dalam identitas sosial memiliki pengaruh dalam mengkonstruksi suatu realitas, baik perorangan maupun lembaga. Peran sosial tersebut tergantung dari dasar pengetahuan dan pandangan objektif sebagai asal-usulnya (Berger, 1991).

Konstruksi realitas dilakukan oleh seluruh media, baik media cetak, media penyiaran maupun media online. Sebuah informasi yang disajikan menjadi sebuah berita dibentuk melalui sudut pandang penulis yang dapat terlihat dari pemilihan bahasa dan cara penyajiannya. Opini penulis yang bersifat subjektif tersebut dibentuk agar berita lebih menarik serta komunikatif (Kuswandi, 2008).

Berdasarkan sudut pandang politik, konstruksi bertujuan untuk membentuk persepsi publik dengan menerapkan tiga hal yaitu pennggunaan simbol, pengemasan, dan malakukan fungsi agenda media. Dalam proses kegiatan tersebut, pengonstruksian turut dipengaruhi oleh faktor internal sebuah media (Hamad, 2004). Konstruksi dapat mencerminkan makna yang ingin disampaikan bahkan ditekankan oleh sebuah media massa. Makna tersebut awalnya bersifat objektif dari suatu media, ketika disampaikan kepada khalayak maka diharapkan dapat menjadi persepsi subjektif. Konstruksi realitas dilakukan dengan menceritakan kembali sebuah fenomena, peristiwa, tokoh maupun benda meliputi hal-hal yang berkaitan dengan politik. Pemilihan kata dan gaya penyajian turut menentukan makna dari sebuah konstruksi realitas (Hamad, 2004).

Menurut pendapat di atas dapat diartikan bahwa pemberitaan yang dilakukan oleh media tidak dapat dipastikan menggambarkan realitas sebenarnya. Realitas yang terjadi dalam masyarakat dikonstruksikan oleh media, baik melaluibahasa maupun penyajiannya. Konstruksi tersebut menjadi berita yang disebarkan kepada khalayak luas, sehingga masyarakat memiliki pandangan yang subjektif terhadap berita tersebut.
Realitas yang terjadi dalam kehidupan sosial dimasyarakat tidak semerta-merta turun dari langit, melainkan dibentuk dan dikonstruksi. Realitas plural yang menerpa secara terus menerus akan menjadikan realitas tersebut bersifat subjektif padahal asalnya dari pemahaman objektif. Begitu pula yang dilakukan oleh sebuah lembaga media ketika melakukan pemberitaan terhadap suatu realitas yang terjadi di masyarakat, dalam konteks ini yaitu media Republika.co.id mengangkat realitas mengenai revisi Undang-Undang KPK dalam portal beritanya pada bulan Februari 2016.

\section{Metode Penelitian}

Penelitian ini menggunakan paradigma konstruktivis yang memandang bahwa dalam proses penulisan berita terdapat beberapa faktor yang berpengaruh atau berperan yang dianggap tidak bersifat general. Paradigma konstruktivis melihat pengemasan sebuah berita revisi Undang-Undang KPK sebagai suatu konstruksi yang memang diciptakan oleh media online Republika. Penyajian melalui dua sudut pandang sekaligus yang dilakukan Republika.co.id dianggap memiliki maksud tertentu melalui penekanan. Penekanan tersebut ditunjukan dengan seringnya Republika.co.id menyajikan berita revisi Undang-Undang KPK di bulan Februari.

Penelitian ini menggunakan pendekatan kualitatif. Miles dan Huberman (1984) menjelaskan bahwa penelitian kualitatif merupakan suatu proses yang bersifat investigasi. Peneliti memaknai suatu fenomena sosial dengan membandingkan, membedakan, mengkategorikan, mengklasifikasikan objek penelitian. Penelitian kualitatif mengeksplorasi dan menginterpretasikan makna yang dipandang objektif oleh seseorang maupun sekelompok orang kemudian dianggap berangkat dari masalah sosial. Penelitian kualitatif terfokus pada pemahaman bagaimana sesuatu itu muncul (Creswell, 2015). Berita revisi Undang-Undang KPK dianggap sebagai sebuah fenomena sosial yang disajikan oleh seluruh media online. 
Pendekatan kualitatif melihat bahwa pemberitaan Republika.co.id pada bulan Februari memiliki perbedaan dari segi frekuensi pemberitaan yang lebih tinggi dibanding media online lain. Fenomena pemberitaan tersebut dianggap bahwa media Republika.co.id ingin menyampaikan makna tertentu melalui kemasan berita-berita yang disajikannya melalui dua sudut pandang sekaligus.

Oleh karena itu, penelitian ini menjadikan berita Republika.co.id sebagai objek penelitian, sehingga yang menjadi unit analisis dalam penelitian ini adalah kosakata, gambar, dan lokasi kata yang terdapat dalam berita Republika.co.id mengenai revisi Undang-Undang KPK periode bulan Februari 2016.

Teknik pengumpulan data yang akan dilakukan dalam penelitian ini adalah dokumentasi. Dalam penelitian ini, dokumen yang dikumpulkan berupa berita dari sebuah media online, yaitu Republika.co.id. Dokumen berupa berita-berita tersebut akan dianalisis dan diidentifikasi oleh peneliti untuk menjawab rumusan masalah terkait konstruksi berita oleh Republika.co.id. Dokumentasi dilakukan dengan mengumpulkan berita-berita revisi Undang-Undang KPK yang dimuat di portal media Republika.co.id. Berita diambil dari hasil pencarian dalam beranda Republika.co.id dengan tertanda \#Revisi Uu Kpk. Jumlah berita di bulan Februari 2016 adalah 305 buah berita. Pada satu bulan tersebut, jumlah penerbitan berita per harinya bervariasi dari skala 0 sampai 50 artikel berita. Guna mempermudah proses analisis, maka penelitian ini memilih tiga edisi tanggal yang memiliki jumlah tertinggi dalam bulan Februari 2016, yaitu tanggal 17 Februari 2016 (26 berita), 22 Februari 2016 (50 berita), dan 23 Februari 2016 (28 berita).

Selain artikel berita Republika.co.id, penelitian ini turut melibatkan Republika Epaper sebagai rujukan dalam pemilihan berita untuk dijadikan data analisis. Republika Epaper merupakan koran harian dalam format digital yang isinya sama dengan Republika dalam format surat kabar. Teknik dokumentasi artikel berita dilakukan dengan cara memilih sejumlah berita di Republika.co.id yang dimuat pula dalam Republika Epaper edisi tanggal 17, 22, dan 23 Februari 2016. Epaper yang dimana sebagai acuan digunakan untuk mengetahui bingkai Republika.co.id seutuhnya, karena pada dasarnya berita Republika.co.id merupakan bagian dari berita Republika Eapaper. Hal ini juga dapat berguna sebagai justifikasi agar dapat mendapatkan frame Republika.co.id secara akurat.

Dalam penelitian analisis framing terhadap konstruksi berita revisi Undang-Undang KPK ini, peneliti secara mandiri melakukan seluruh proses, dari tahap perencanaan, penentuan, pengumpulan data, penafsiran makna dari analisis data, hingga pembuat hasil penelitian akhir. Penelitian ini menggunakan analisis framing model Zhongdang Pan \& Gerald M. Kosicki yang memiliki empat perangkat framing yang terdiri dari sintaksis, skrip, tematik, dan retoris. Sejumlah unsur tersebut akan menunjukan framing dari suatu media (Eriyanto, 2012). Dalam proses analisisnya, model tersebut mengoperasionalkan empat struktur yang muncul dalam teks secara keseluruhan dengan menghubungkan suatu ide berita dengan elemen yang berbeda dalam teks, seperti kutipan, latar informasi, pemakaian kata dalam teks. Dalam penelitian ini, empat perangkat framing Pan dan Kosicki tersebut akan digunakan dalam proses identifikasi yang dilakukan terhadap teks berita Republika.co.id terkait isu revisi UndangUndang KPK di bulan Februari 2016.

\section{Hasil dan Penelitian}

Pemberitaan revisi Undang-Undang KPK yang sempat surut dan mencuat kembali pada Februari 2016 menjadi isu yang cukup disorot oleh Republika.co.id. Hal tersebut terlihat dengan jumlah pemberitaan terkait revisi Undang-Undang KPK yang lebih tinggi dibandingkan dengan media online lain. Analisis data konstruksi berita media Republika.co.id dilakukan terhadap sembilan artikel berita mengenai Revisi Undang-Undang 
KPK yang disajikan pada bulan Februari 2016. pada struktur sintaksis yang meliputi judul, lead,

Tabel 1.1

Berita Republika.co.id

\begin{tabular}{|c|c|c|c|}
\hline No & $\begin{array}{l}\text { Hari/Tanggal } \\
\text { Terbit Epaper }\end{array}$ & $\begin{array}{l}\text { Judul Berita di } \\
\text { Republika.co.id }\end{array}$ & $\begin{array}{c}\text { Potongan Berita di } \\
\text { Lain Hari }\end{array}$ \\
\hline 1. & $\begin{array}{l}\text { Rabu, 17 Februari } \\
2016\end{array}$ & $\begin{array}{l}\text { 1. JK: Pemberian } \\
\text { Kewenangan SP3 Malah } \\
\text { Memperkuat KPK } \\
(03.01 \text { WIB })\end{array}$ & $\begin{array}{l}\text { 1. Ini Saran Mahfud } \\
\text { Soal Kewenangan } \\
\text { Penyadapan KPK } \\
\text { (terbit 16/2/2016, } \\
\text { 15.56 WIB) } \\
\text { 2. Koalisi Masyarakat } \\
\text { Sipil dan KPK } \\
\text { Sepakat Tolak Revisi } \\
\text { UU KPK (terbit } \\
\text { 16/2/2016, } 15.30 \\
\text { WIB) }\end{array}$ \\
\hline 2. & $\begin{array}{l}\text { Senin, } 22 \text { Februari } \\
2016\end{array}$ & $\begin{array}{l}\text { 1. MUI Tolak Revisi UU } \\
\text { KPK (07.24 WIB) }\end{array}$ & $\begin{array}{l}\text { 1. Ini Ancaman Ketua } \\
\text { KPK Jika UU KPK } \\
\text { Tetap Direvisi } \\
\text { (terbit } 21 / 2 / 2016, \\
\text { 16.51 WIB)P } \\
\text { 2. PDIP Yakin } \\
\text { Presiden Jokowi } \\
\text { takkan Batalkan } \\
\text { Revisi UU KPK } \\
\text { (terbit } 21 / 2 / 2016, \\
\text { 09.45 WIB) }\end{array}$ \\
\hline 3. & $\begin{array}{l}\text { Selasa, } 23 \text { Februari } \\
2016\end{array}$ & $\begin{array}{l}\text { 1. Pemerintah tak } \\
\text { Berencana Cabut Revisi } \\
\text { UU KPK (19.40 WIB) }\end{array}$ & $\begin{array}{l}\text { 1. DPR Sebut Gerakan } \\
\text { Antirevisi UU KPK } \\
\text { Bahayakan Sistem } \\
\text { Ketatanegaraan } \\
\text { (terbit 22/2/2016, } \\
\text { 17.56 WIB) } \\
\text { 2. Tolak Revisi } \\
\text { UU, KPK: Sikap } \\
\text { Pimpinan tak } \\
\text { Main-Main (terbit } \\
\text { 22/2/2016, } 14.07 \\
\text { WIB) }\end{array}$ \\
\hline
\end{tabular}

Kesembilan artikel berita Republika. co.id mengenai revisi Undang-Undang KPK memperlihatkan bahwa Republika.co.id melakukan pembingkaian dengan menonjolkan keempat struktur penulisan berita. Pertama, pernyataan dan kutipan; kedua, pada struktur skrip dengan menekankan unsur who dan what; ketiga, pada struktur tematik mencakup penonjolan tema berita dan koherensi; keempat, struktur retoris meliputi penonjolan foto. Bagian- 
bagian tersebut mendominasi pemberitaan Republika.co.id.

Framing Republika.co.id mengalami perubahan pada saat sebelum adanya keputusan presiden dan setelah munculnya hasil pembahasan revisi Undang-Undang KPK dari presiden. Perubahan tersebut khususnya terlihat pada struktur tematik dan struktur skrip pada pemberitaan. Pada struktur tematik, perubahan diperlihatkan melalui pengangangkatan tema berita. Sebelum keputusan presiden disahkan, Republika.co.id mengangkat dua tema dalam pemberitaan tanpa koherensi. Sedangkan setelah munculnya keputusan presiden, pemberitaan hanya mengangkat satu tema berita saja serta mencantumkan koherensi sebagai hubungan antarkalimat dalam beritanya. Misalnya pada berita yang berjudul "JK: Pemberian Kewenangan SP3 Malah Memperkuat KPK" dan "DPR Sebut Gerakan Antirevisi UU KPK Bahayakan Sistem Ketatanegaraan".

Pada struktur skrip, perubahan terletak pada cara penyajian keterangan unsur who dari narasumber. Jauh sebelum adanya keputusan presiden, keterangan who ditampilkan melalui identitas personal dari narasumber berupa nama serta status pejabatnya. Contohnya seperti dalam pemberitaan "Ini Saran Mahfud Soal Kewenangan Penyadapan KPK". Sementara setelah adanya keputusan dari presiden, keterangan who dari narasumber tampil dengan mengedepankan asal institusi/lembaga seperti dalam berita berjudul "Tolak Revisi UU, KPK: Sikap Pimpinan tak Main-Main".

Penyajian berita Republika.co.id juga memiliki perbedaan ketika menampilkan narasumber yang berasal dari kelompok agama. Perbedaan diperlihatkan pada struktur retoris. Republika.co.id tidak menampilkan sosok narasumber pada foto dan menggunakan gaya bahasa yang plural dalam berita.

Berdasarkan hasil analisis, pemberitaan Republika.co.id mengenai revisi UndangUndang KPK memperlihatkan adanya kecenderungan tidak berpihak kepada sisi pendukung revisi Undang-Undang KPK. Saat menampilkan pihak yang mendukung revisi Undang-Undang KPK, Republika.co.id seolah menyiratkan perlawanan terhadap narasumber. Hal itu diperoleh berdasarkan perangkat framing model Pan dan Kosicki, yaitu struktur sintaksis, skrip, tematik, dan retoris.

Pada struktur sintaksis, Republika. co.id lebih menonjolkan pernyataan narasumber dalam berita. Pernyataan tersebut merupakan bentuk kalimat tidak langsung dari narasumber yang diparaphrasekan oleh Republika.co.id. Walaupun inti dari pernyataan tidak hilang, namun pemahaman pembaca dapat berbeda ketika cara penyampaian dari isi pernyataan berubah. Pernyataan yang lebih dominan dalam pemberitaan tidak mampu menggeser persepsi lain dalam pembahasan revisi Undang-Undang KPK, khususnya persepsi yang berseberangan dari pandangan narasumber. Dapat dikatakan bahwa Republika.co.id berupaya menjaga persepsi lain dari pihak yang menolak revisi Undang-Undang KPK agar tetap diperhitungkan oleh khalayak.

Struktur skrip dalam pemberitaan muncul dengan menekankan unsur who dan unsur what. Kedua unsur ini ditampilkan pada bagian awal berita yang memperlihatkan pemaknaan dari Republika.co.id. Unsur who memperlihatkan keterangan identitas secara personal dari narasumber dan unsur what muncul dengan menggambarkan keberpihakan dari narasumber terhadap revisi Undang-Undang KPK.

Maka dari itu, dapat dikatakan bahwa Republika.co.id ingin memfokuskan pemikiran pembaca terbatas pada subjek dan bentuk sikap yang diambil dalam pembahasan revisi UndangUndang KPK, baik mendukung maupun menolak revisi. Republika.co.id melakukan penekanan pada bagian-bagian tertentu, seperti judul, foto, lead, agar khalayak lebih mengingat dan melupakan aspek lain yang tidak diberitakan. Hal ini memperlihatkan bahwa Republika. co.id melakukan seleksi, menghubungkan, dan menonjolkan fakta-fakta dalam suatu realitas sehingga maknanya lebih tersampaikan kepada pembaca (Eriyanto, 2012). 
Pada pemberitaan yang menampilkan pihak pendukung revisi Undang-Undang KPK terdapat kesamaan dengan salah satu penelitian terdahulu yang terlihat pada struktur sintaksis dan skrip dalam pemberitaan. Penelitian skripsi berjudul "Konstruksi Berita Penyelenggaraan Ibadah Haji 2015" (Analisis Framing Robert Entman di Republika online dan Kompas. com) mengatakan bahwa narasumber dipilih berdasarkan fakta yang ingin disampaikan dalam pemberitaan (Triyandari, 2016). Hal tersebut juga dilakukan saat Republika.co.id menampilkan pihak yang mendukung revisi Undang-Undang KPK. Narasumber-narasumber terpilih disajikan untuk menggambarkan sikap mereka yang mendukung Undang-Undang KPK untuk direvisi. Hal ini menunjukkan bahwa Republika. co.id menganggap cara penyajian narasumber dalam pemberitaan dapat menentukan persepsi yang dibentuk oleh pembaca.

Selanjutnya, pemberitaan Republika. co.id yang menampilkan pihak pendukung revisi Undang-Undang KPK juga diperlihatkan pada struktur tematik dalam pemberitaan. Republika. co.id mengangkat dua tema pemberitaan yang terlihat kurang selaras antara satu dengan yang lain. Hal tersebut mencerminkan adanya pandangan pro dan kontra terhadap revisi Undang-Undang KPK. Tema pemberitaan kedua yang diangkat seolah menepis pendapat dalam tema pertama. Dapat dikatakan bahwa Republika.co.id tidak setuju untuk mendukung pembahasan revisi Undang-Undang KPK. Bila Republika.co.id setuju, kemungkinan pemberitaan akan mengangkat tema berita yang saling memperkuat. Hal tersebut dapat dikatakan sebagai pandangan Republika.co.id (Sobur, 2012).

Pada struktur retoris, Republika.co.id menojolkan foto sosok narasumber pada bagian awal berita. Penonjolan foto tersebut memiliki keterkaitan dengan struktur skrip dalam berita, karena foto berperan sebagai aspek pendukung struktur skrip dimana Republika. co.id menekankan unsur who dari narasumber. Artinya, Republika.co.id menampilkan foto untuk menarik perhatian agar sosok yang ditampilkan pada berita lebih melekat dalam memori pembaca.

Akan tetapi, hal tersebut tidak berlaku kepada seluruh berita Republika.co.id. Pada pemberitaan revisi Undang-Undang KPK terdapat perbedaan konstruksi ketika Republika. co.id meyajikan narasumber yang berasal dari kelompok agama. Perbedaan tersebut terlihat pada struktur retoris yang menunjukkan Republika.co.id tidak menonjolkan sosok narasumber pada foto. Selain itu, Republika. co.id cenderung menggunakan gaya bahasa plural dalam pemberitaan untuk menemukan makna yang beragam.

Pembingkaian seperti hal diatas tidak terlepas dari ideologi media yang dimiliki Republika.co.id. Hal ini dikarenakan Republika. co.id merupakan media yang lahir dari komunitas Islam dan pada akhirnya menerapkan nilai-nilai keyakinannya saat memahami sebuah realitas revisi Undang-Undang KPK. Ideologi Republika.co.id dibangun dari pengalaman dan nilai-nilai yang berkembang ketika media mulai dibangun (Rusadi, 2015). Aspek agama dalam Republika.co.id cukup melekat sesuai dengan asal-usul Republika dari Ikatan Cendekiawan Muslim Indonesia (ICMI). Hal tersebut ternyata memberikan pengaruh terhadap pemberitaan yang dilakukan Republika.co.id ketika menyajikan pendapat narasumber yang berasal dari sebuah kelompok agama.

Pengaruh terhadap pemberitaan sangat terlihat ketika mencantumkan pendapat narasumber yang menyebutkan kata 'jihad' untuk menentang revisi Undang-Undang KPK. Narasumber yang ditampilkan Republika.co.id berasal dari MUI. Dapat disimpulkan bahwa Republika.co.id sependapat bila tindakan korupsi dianggap sebagai hal yang diharamkan oleh agama Islam. Jika revisi Undang-Undang KPK membuat KPK menjadi lemah dalam memberantas tindak korupsi, maka Republika. co.id turut mengganggap pendukung revisi Undang-Undang KPK sebagai pihak kafir yang patut dilawan secara jihad. 
Perbedaan konstruksi dalam hal ini dapat mencerminkan bahwa Republika.co.id seolah ingin tetap menjaga reputasi narasumber yang berasal dari kelompok agama, serta menekankan perspektif yang menjunjung agama Islam. Framing ini terlihat pada berita berjudul "MUI Tolak Revisi UU KPK" dan "Ini Ancaman Ketua KPK Jika UU KPK Tetap Direvisi”.

Hal ini serupa dengan penelitian terdahulu yang berjudul "Pembingkaian Berita Mengenai Pembekuan PSSI oleh Menteri Pemuda dan Olahraga yang Berujung Sanksi FIFA". Republika.co.id memberikan citra positif kepada kelompok Islam, dalam penelitian tersebut adalah partai-partai Islam. Sedangkan PDIP cenderung dikonstruksikan secara negatif oleh Republika.co.id (Sari, 2015). Terdapat kesamaan dalam penelitian dimana Republika. co.id menjaga citra dari narasumber yang berasal dari kelompok agama, serta tidak menunjukkan keberpihakkannya saat memberitakan PDIP.

Dapat dikatakan bahwa Republika.co.id ingin menggambarkan dan membentuk perspektif yang baik terhadap agama Islam. Siapapun dan apapun agamanya yang merepresentasikan agama Islam dengan baik dari segi ilmu ajaran maupun pemikiran akan diakomodasi oleh Republika. co.id melalui pemberitaannya. Hal ini terbukti ketika Republika.co.id tetap mengakomodasi opini narasumber yang berasal dari kelompok non Islam yang sependapat untuk menolak revisi Undang-Undang KPK. Cara penyajian dalam pemberitaan Republika.co.id telah membuktikan bahwa media Republika merupakan sebuah apartus yang memiliki kewenangan privat sehingga mampu menjalankan sebuah ideologi tertentu (Althusser, 2008). Republika.co.id dapat senantiasa bertugas menjalani kegiatan produksi berita sesuai dengan ideologi tertentu yang dimiliki.

Hal tersebut memiliki kaitan dengan visi dari Republika.co.id untuk membangun umat Islam yang cerdas, moderat, dan berdaya. Penggambaran agama Islam yang baik merupakan salah satu strategi yang dilakukan oleh Republika.co.id untuk mencapai visi tersebut. Ketika agama Islam sudah dipandang baik secara ilmu ajaran, maka pemikiran dan sikap dari umatnya pun turut dipandang baik sehingga mampu mewujudkan umat dengan karakteristik yang dimaksud oleh Republika. co.id. Berdasarkan ideologinya, pemberitaan Republika.co.id menunjukkan tindak korupsi dianggap sebagai bentuk kejahatan yang haram dan perlu dituntaskan dengan cara berjihad untuk menentang pihak yang mendukung revisi Undang-Undang KPK.

Adapun penelitian terdahulu yang menunjukkan penggambaran agama Islam, yaitu skripsi berjudul "Konstruksi Berita Penyelenggaraan Ibadah Haji 2015" (Analisis Framing Robert Entman di Republika online dan Kompas.com). Bila dibandingkan dengan penelitian ini, penelitian karya Gita Agil Triyandari tidak melakukan keberpihakkan dan sebaliknya mengkritisi kementrian agama selaku penyelanggara ibadah haji. Republika. co.id memberikan evaluasi terhadap pelayanan dari kementrian agama (Triyandari, 2016). Akan tetapi, maksud Republika.co.id sama halnya ingin agama islam dianggap baik oleh khalayak dengan cara kritik yang berisi pembenaran pelayanan yang seharusnya dilakukan kementrian agama dalam menyelenggarakan ibadah haji, bukan ingin mengangkat atau menurunkan citra dari kementrian agama.

Dapat disimpulkan bahwa demi membentuk pandangan yang baik terhadap agama Islam, Republika.co.id tidak harus memandang sosok dari individu/kelompok. Tidak menutup kemungkinan Republika.co.id menunjukkan tidak berpihak pada narasumber yang berasal dari golongan agama Islam jika dinilai tidak benar oleh Republika.co.id, karena hal yang terpenting adalah Islam sebagai agama dipandang baik oleh masyarakat.

Selain adanya perbedaan berdasarkan ideologi, konstruksi berita yang menampilkan pihak pendukung revisi Undang-Undang KPK juga mengalami perubahan setelah pengesahan keputusan presiden mengenai pembahasan revisi pada tanggal 22 Februari 2016. Sebelum 
adanya keputusan presiden tersebut, Republika. co.id terlihat tidak segan untuk menggambarkan perspektif pro dan kontra dalam pembahasan revisi. Namun, setelah adanya keputusan presiden, Republika.co.id menunjukkan perubahan yang diperlihatkan pada struktur skrip dan tematik.

Struktur skrip dalam pemberitaan memperlihatkan keterangan who berubah dengan mengedepankan asal kelembagaan. Berdasarkan struktur tematik, Republika.co.id mengangkat satu tema pemberitaan serta menggunakan koherensi pembeda sebagai hubungan antarkalimat. Misalnya pada berita berjudul "JK: Pemberian Kewenangan SP3 Malah Memperkuat KPK" dan "Pemerintah tak Berencana Cabut Revisi UU KPK". Dapat dikatakan bahwa setelah pembahasan revisi Undang-Undang KPK mencapai tahap keputusan dari presiden, Republika.co.id mengurangi perspektif yang mencolok dari sisi pro dan kontra, tetapi tetap memperlihatkan kecenderungannya tidak berpihak dalam pemberitaan.

Penggambaran pro kontra yang mencolok sebelum adanya keputusan presiden terlihat sebagai agenda media Republika.co.id. Perspektif pro kontra menjadi isu dalam masyarakat yang disebut agenda publik. Kemudian, muncul kebijakan baru yang disahkan oleh presiden untuk menunda pembahasan revisi UndangUndang KPK. Perspektif pro kontra sebagai agenda Republika.co.id berubah menjadi tidak terlihat secara jelas. Ternyata agenda Republik. co.id mendapatkan pengaruh besar dari sumbersumber luar media yang berpengaruh dalam kehidupan sosial (Littlejohn, 2008). Dalam hal ini, sumber luar media tersebut adalah keputusan presiden sebagai agenda kebijakan. Sebagai kepala negara, presiden memiliki peran yang sangat besar dan apapun kebijakan yang dikeluarkan oleh presiden akan dianggap penting. Hal tersebut cukup diperhatikan oleh Republika.co.id dan menjadi parameter dalam melakukan pemberitaannya.

Setelah adanya keputusan presiden, perspektif pro kontra dalam revisi Undang-
Undang KPK tidak lagi secara jelas terlihat dalam pemberitaan Republika.co.id. Maka dapat disimpulkan bahwa keputusan presiden yang merupakan agenda kebijakan memiliki pengaruh terhadap frame media Republika.co.id dalam mengkonstruksi realitas mengenai revisi Undang-Undang KPK.

Kebijakan dari presiden tersebut merupakan kebijakan politik dari sebuah sistem yang berlaku di Indonesia. Ketika kebijakan politik berperan dalam sistem media massa dalam sebuah negara, maka hal tersebut dapat mencerminkan sistem politik yang berlaku pada negara tersebut (Hamad, 2012). Dapat dikatakan bahwa sistem politik yang berlaku di Indonesia menaruh kekuasaan yang cukup besar pada presiden sebagai pimpinan tertinggi di Indonesia. Kekuasaan tersebut mampu mempengaruhi sistem agenda media yang ada di Indonesia, termasuk Republika.co.id.

Di samping itu, media dan sebuah kebijakan kerap memiliki hubungan yang saling membutuhkan. Pihak pemerintah memerlukan media sebagai saluran komunikasi politik. Media pun turut membutuhkan informasi dari pihak tersebut karena bobot nilai beritanya cukup tinggi menyangkut sebuah kebijakan. Pihak pemerintah sebagai pembuat kebijakan memang memiliki kekuatan dalam sebuah negara, akan tetapi media massa mampu ikut serta dalam mengubah sistem politik melalui pemberitaannya (Hamad, 2012). Dapat dikatakan bahwa penegasan Republika.co.id melalui pemberitaannya adalah bentuk partisipasi Republika.co.id dengan cara membentuk opini yang bersifat umum mengenai upaya memerangi korupsi serta perlawanan terhadap pendukung revisi Undang-Undang KPK. Hal tersebut dianggap sebagai "hidden agenda" dari Republika.co.id.

Realitas revisi Undang-Undang KPK tidak semerta-merta ditampilkan begitu saja oleh Republika.co.id, melainkan disajikan melalui proses konstruksi. Penggambaran yang diperoleh telah membuktikan bahwa Republika. co.id melakukan konstruksi dalam menampilkan berita terkait revisi Undang-Undang KPK. 
Pengkonstruksian berita berdasarkan keempat struktur dalam pemberitaan sama halnya dengan proses dialektika, dimana adanya tahap eksternalisasi, objektivasi, dan internalisasi (Berger, 1991).

Republika.co.id menyoroti realitas revisi Undang-Undang KPK dan menganggap bahwa informasi dari realitas tersebut dibutuhkan oleh masyarakat karena dampaknya menentukan kesejahteraan masyarakat, tahap ini menunjukkan terjadinya tahap eksternalisasi. Realitas tersebut diserap dan dipahami oleh Republika. co.id, sehingga melahirkan representasi sesuai dengan perspektifnya. Representasi ditunjukkan dengan adanya penekanan dan penonjolan pada struktur sintaksis, skrip, tematik, dan retoris dalam pemberitaan yang dilatarbelakangi oleh cara pandang Republika.co.id terhadap realitas revisi Undang-Undang KPK. Hal tersebut telah memperlihatkan terjadinya tahap objektivasi.

PandanganRepublika.co.idmenghasilkan sebuah makna yang dapat disajikan melalui cara penyajian berita, sehingga hal tersebut memiliki peran yang besar dalam mengubah pandangan objektif dari Republika.co.id menjadi pandangan subjektif ketika beritanya dikonsumsi oleh khalayak. Tahap internalisasi sangat terasa ketika membaca berita Republika.co.id yang terlihat memiliki kecenderungan tidak berpihak terhadap pihak yang mendukung revisi UndangUndang KPK.

Konstruksi dilakukan oleh Republika. co.id dalam upaya menyampaikan sebuah makna dari realitas revisi Undang-Undang KPK. Sadar atau tidak, faktor yang mempengaruhi konstruksi tersebut memungkinkan makna yang diperoleh komunikan berbeda dengan makna dari realitas sebenarnya. Sehingga konstruksi realitas yang tersampaikan bukanlah realitas kedua melainkan dapat membentuk realitas lain (Hamad, 2010). Republika.co.id dan media lainnya tidak dapat dipastikan memiliki pandangan yang sama terhadap suatu realitas yang terjadi, sehingga makna yang terbentuk dalam kognitif pembaca belum tentu sesuai dengan makna yang seharusnya pada realitas yang pertama.
Bila dilihat dari sudut pandang politik, konstruksi yang dilakukan Republika.co.id mencakup kegiatan penggunaan simbol, pengemasan, serta melakukan fungsi agenda media(Hamad, 2004). Konstruksi yang dilakukan oleh Republika.co.id cenderung berfokus pada strategi pengemasan berita. Berdasarkan tujuan, konstruksi dibentuk untuk menghasilkan opini publik yang sesuai dengan opini Republika. co.id. Artinya, Republika.co.id mengharapkan pemikiran pembaca turut menolak revisi UndangUndang KPK seperti halnya yang dipahami oleh Republika itu sendiri.

Menurut teori konstruksi realitas sosial, Republika.co.id sebagai media massa dinilai memiliki kekuatan yang besar dalam membentuk opini khalayak. Adapun kaitannya dengan fungsi agenda media, perubahan konstruksi merupakan upaya dari Republika.co.id untuk menanamkan gambaran realitas dalam pemikiran pembaca sebagaimana pengonstruksiannya.

Berdasarkan konstruksi pemberitaannya, Republika.co.id tidak melakukan manipulasi total terhadap realitas revisi Undang-Undang KPK. Akan tetapi, Republika.co.id melakukan transfer pemikiran kepada pembaca melalui bahasa (teks) dan cara penyajian berita (Hamad, 2012). Republika.co.id menekankan cara pengemasan berita sebagai bentuk pengendalian pola pikir pembaca menjadi sebuah persepsi yang sesuai dengan pandangan Republika.co.id. Pada konstruksi yang melibatkan ideologi, Republika.co.id seolah memaksa pembaca untuk beranggapan bahwa tindak korupsi patut untuk dilawan serta menggunakan pemberitaannya sebagai "senjata" melawan korupsi.

Pengonstruksian dinilai ampuh dalam menyampaikan maksud Republika.co.id kepada pembacanya. Bahasa dalam teks berita -baik verbal (kata tertulis) maupun nonverbal (gambar, tabel, grafik, foto)- memiliki kekuatan untuk menentukan makna yang muncul dalam pemikiran khalayak (Hamad, 2012). Republika. co.id tidak lagi menceritakan kembali realitas mengenai revisi Undang-Undang KPK, bahkan Republika.comid juga menciptakan sebuah 
realitas bahwa tindak korupsi adalah haram dan wajib diperangi.

\section{Simpulan}

Konstruksi berita Republika.co.id tentang revisi Undang-Undang KPK terlihat menunjukkan kecenderungan tidak berpihak kepada pendukung revisi. Republika.co.id memliki ideologi yang berperan pada proses konstruksi realitas revisi Undang-Undang KPK. Ideologi Republika.co.id diterapkan pada cara penyajian berita ketika Republika. co.id ingin menggambarkan Islam sebagai suatu ajaran agama yang baik kepada khalayak. Penggambaran tersebut dilakukan tanpa harus memandang subjek yang diangkat, sekalipun berasal dari golongan non Islam.

Selain ideologi, konstruksi Republika. co.idjugaturut dipengaruhi oleh agendakebijakan berupa keputusan presiden yang mengakibatkan perubahan frame berita Republika.co.id. Perubahan tersebut diperlihatkan saat sebelum dan setelah presiden memutuskan untuk menunda pembahasan revisi. Pada tanggal 22 Februari 2016. Konstruksi pemberitaan yang dilakukan oleh Republika.co.id dianggap sebagai penerapan teori konstruksi realitas sosial yang mencakup tiga tahap dalam proses dialetika. Tiga tahap tersebut terdiri dari eksternalisasi, objektivasi, dan internalisasi.

Maka dari itu, dapat disimpulkan bahwa Republika.co.id merupakan sebuah media online yang memiliki landasan pemikiran tertentu dalam memahami isu revisi UndangUndang KPK, baik dari segi ideologi maupun agenda medianya. Landasan pemikiran tersebut akan menghasilkan sebuah penafsiran yang menetapkan cara penyajian berita. Republika. co.id meyakini bahwa cara penyajian sebuah berita dapat membentuk persepsi pembaca sesuai dengan maksud yang ingin disampaikan oleh Republika.co.id.

Sebagai pihak yang menolak, Republika. co.id menentang seluruh pihak yang mendukung pembahasan revisi Undang-Undang KPK karena bagi Republika.co.id Undang-Undang Nomor 30 Tahun 2002 terkait KPK tidak perlu direvisi.
Berdasarkan cara pengemasan dalam konstruksi isu revisi Undang-Undang KPK, Republika.co.id berupaya menegaskan kepada khalayak untuk turut memerangi korupsi yang dinilai haram dari segi agama Islam. Secara terperinci, kesimpulan tersebut diperlihatkan pada keempat struktur dalam pemberitaan, yakni sebagai berikut:

1. Struktur sintaksis menunjukkan Republika.co.id ingin persepsi dari pihak yang menolak revisi Undang-Undang KPK tetap diperhitungkan oleh khalayak. Penonjolan pernyataan atau kutipan dalam pemberitaan dianggap penting oleh Republika.co.id untuk membentuk sebuah perspektif kepada pembaca.

2. Pada struktur skrip, Republika.co.id memandang unsur subjek (who) dan bentuk sikap yang diambil (what) dalam pemberitaan cukup berperan untuk memfokuskan pemikiran pembaca.

3. Berdasarkan struktur tematiknya, pengangkatan tema dalam pemberitaan sangat diperhatikan oleh Republika.co.id untuk memperlihatkan keberpihakkan Republika itu sendiri. Jika Republika. co.id cenderung tidak berpihak, maka pemberitaan akan mengangkat dua tema berita yang terlihat tidak selaras. Sebaliknya jika Republika cenderung berpihak, maka tema pemberitaan yang diangkat memperlihatkan keselarasan.

4. Pada struktur retoris terlihat bahwa Republika.co.id memanfaatkan fungsi gambar/foto dalam pemberitaan untuk memperkuat ingatan pembaca terkait subjek dalam pemberitaan. Republika. co.id menilai sebuah foto dapat menarik perhatian pembaca dan mudah terekam dalam memori pembaca.

\section{Daftar Pustaka}

Althusser, Louis. 2008. Tentang Ideologi Marxisme Strukturalis, Psikoanalisis, Cultural Studies. Yogyakarta: Jalasutra.

Berger, Peter L. Dan Thomas Luckmann. 1991. The Social Construction of 
Reality: Treatise in the Sociology of Knowledge. London: Penguin. Creswell, Jhon W. 2015. Reseacrh Design: Pendekatan Kualitatif, Kuantitatif dan Mixed. Pustaka Pelajar. Yogyakarta. Eriyanto. 2012. Analisis Framing:Konstruksi, Ideologi, dan Politik Media. Yogyakarta: LKiS. Hamad, Ibnu. 2004. Konstruksi Realitas Politik dalam Media Massa. Jakarta: Granit. . 2010. Komunikasi Sebagai

Wacana. Jakarta: La Tofi Enterprise Kuswandi, Wawan. 2008. Komunikasi Massa (Analisis Interaktif Budaya Massa). Jakarta: Rineka Cipta. Kovach, Bill dan Tom Rosenstiel. 2006. Sembilan Elemen Jurnalisme. Jakarta: Yayasan Pantau.

Littlejohn, Stephen W \& Karen A Foss. 2008. Theory of Human Communication, $9^{\text {th }}$ edition. Thomson Wadsworth. . 2013. Komunikasi Dakwah (Pendekatan Praktis). Bandung. Rusadi, Udi. 2015. Kajian Media: Isu Ideologis dalam Perspektif, Teori dan Metode. Jakarta: PT. RajagrafindoPersada. Sobur, Alex. 2012. Analisis Sari, Siska Nur Indah. 2015. "Pembingkaian Berita Mengenai Kasus Pembekuan PSSI Oleh Menteri Pemuda dan Olahraga yang Berujung Sanksi FIFA" (Analisis Framing Robert Entman pada Media online Republika.co.id periode 25 April-7 Juni 2015). Fakultas Ilmu Komunikasi. Universitas Pancasila. Jakarta.

Teks Media: Suatu Pengantar untuk Analisis Wacana, Analisis Semiotik, dan Analisis Framing. Bandung: Remaja Rosdakarya. Triyandari, Gita Agil. 2016. "Konstruksi Berita Penyelenggaraan Ibadah Haji 2015" (Analisis Framing Robert Entman di Republika online dan Kompas. com). Fakultas Ilmu Komunikasi. Universitas Pancasila. Jakarta.

\section{Internet}

Antaranews.com. 2015. UU KPK: bukan revisi undang-undang biasa. Dalam http://www. antaranews.com/berita/504032/uu-kpk-bukanrevisi-undang-undang-biasa, akses 30 Maret 2016, pukul 18.44 WIB.

Antaranews.com. 2016. Maarif Sarankan Presiden Jokowi Bujuk PDIP Tolak Revisi. Dalam http://www.antaranews.com/berita/545923/ maarif-sarankan-presiden-jokowi-bujuk-pdiptolak-revisi, akses 30 Maret 2016, pukul 20.45 WIB.

Badan Pembinaan Hukum Nasional. 2011. Undang-Undang Nomor 30 Tahun 2002 Tentang Komisi Pembarantasan Korupsi. Dalam http://acarapidana.bphn.go.id/2011/11/30/ undang-undang-nomor-30-tahun-2002-komisipemberantasan-korupsi-4/, akses 3 April 2016, pukul 12.16 WIB.

Harian Jurnal Asia. 2016. Revisi UU KPK. Dalam http://www.jurnalasia.com/2016/02/23/ revisi-uu-kpk-2/, akses 30 Maret 2016, pukul 18.44 WIB.

Kpk.go.id. 2015. Capaian dan Kinerja KPK di Tahun 2015. Dalam http://www.kpk.go.id/id/ berita/siaran-pers/3132-capaian-dan-kinerjakpk-di-tahun-2015, akses 23 Agustus 2016, pukul 11.20 WIB.

Kompas.com. 2016. PAN Juga Minta Revisi UU KPK Dicabut dari Prolegnas. Dalam http://nasional.kompas.com/ $\mathrm{read} / 2016 / 02 / 24 / 14352121 /$ PAN.Juga.Minta. Revisi.UU.KPK.Dicabut.dari.Prolegnas, akses 30 Maret 2016, pukul 20.45 WIB.

Okezone.com. 2016. Slank Temui Pimpinan dan Gelar Konser di KPK. Dalam http://news. okezone.com/read/2016/02/22/337/1317921/ slank-temui-pimpinan-dan-gelar-konser-di-kpk, akses 30 Maret 2016, pukul 20.45 WIB. 
Profil Republika. 2013. Republika. Dalam http:// profil.merdeka.com/indonesia/r/republika/, akses 15 Juni 2016, pukul 24.10 WIB.

Profil Republika.co.id. 2015. Profil. Dalam http://www.republika.co.id/page/about, akses 15 Juni 2016, pukul 24.10 WIB.

Republika.co.id. 2016. Sikap KPK Tolak Revisi UU tak Perlu Berlebihan. Dalam http://www. republika.co.id/berita/nasional/hukum/16/02/19/ o2s9jc385-sikap-kpk-tolak-revisi-uu-tak-perluberlebihan, akses 30 Maret 2016, pukul 20.45 WIB.
Sindonews.com. 2016. Revisi UU Nomor 30 Tahun 2002 Dinilai 90\% Melemahkan KPK. Dalam http://nasional.sindonews.com/ $\mathrm{read} / 1085004 / 13 /$ revisi-uu-nomor-30-tahun2002-dinilai-90-melemahkan-kpk-1455347267, akses 30 Maret 2016, pukul 20.45 WIB.

Viva.co.id. 2016. Revisi UU KPK, DPR: Kenapa Takut Penyadapan Diatur?. Dalam http://politik. news.viva.co.id/news/read/736665-revisi-uukpk--dpr--kenapa-takut-penyadapan-diatur-, akses 30 Maret 2016, pukul 20.45 WIB. 